\title{
FAKTOR MANUSIA DENGAN TERJADINYA KECELAKAAN KERJA DI SENTRA INDUSTRI MEUBEL ALUMINIUM DI KABUPATEN HULU SUNGAI UTARA
}

\author{
Michelle Savitri, Gunung Setiadi, Yohanes Joko Supriadi \\ Poltekkes Kemenkes Banjarmasin Jurusan Kesehatan Lingkungan \\ Jl.H.M. Cokrokusumo No.1 A Kota Banjarbaru \\ Email: michellesavitri@gmail.com
}

\begin{abstract}
Human Factors With The Occurrence Of Work Accidents In Industry Center Of Aluminium Furniture Regency Hulu Sungai Utara . Work accident do not happen by accident but there is. The first group is categorized the $80-85 \%$ of the human factor and 20 $25 \%$ because to mechanical/environmental factors. Human factors that can lead to the occurrence of accidents is worker characteristics (age, education level, work period, and job training), less concentration workers, work discipline (APD) and psychological factors (marital status). The purpose of this analytic research is to know the relation of human factors with the occurrence of accidents. This type of research analytic with cross sectional design. Population of research to 43 people. Data analysis used X2 (Chi Square). The results showed that once a work accident. Many accident as 40 people. The type of accident is slipped (11.6\%), punctured (48.8\%), cut throat (32.6\%). Location of the wound $(69.8 \%)$. The results showed that there is a relationship of age and educational level $(p<0.05)$ with the occurrence of accidents. Control means with makes a comfortable working space, rest enough schedule, procurement of personal protective equipment (PPE) in accordance with the hazard potential
\end{abstract}

Keywords: human factors, occupational accidents, industry Aluminum furniture

\begin{abstract}
Abstrak : Faktor manusia dengan terjadinya kecelakaan kerja di sentra industri meubel aluminium di Kabupaten Hulu Sungai Utara. Kecelakaan kerja tidak terjadi secara kebetulan melainkan ada sebabnya. Dikategorikan yaitu golongan pertama $80-85 \%$ faktor manusia dan 20-25\% mekanis /lingkungan. Faktor manusia yang dapat menyebabkan terjadinya kecelakaan kerja adalah karakteristik pekerja (usia, tingkat pendidikan, masa kerja, dan latihan kerja), kurangnya konsentrasi pada pekerja, disiplin kerja (APD) dan faktor psikologis (status perkawinan). Tujuan utama dari penelitian analitik ini adalah untuk mengetahui hubungan antara faktor manusia dengan terjadinya kecelakaan kerja. Jenis penelitian adalah penelitian analitik dengan rancangan cross sectional. Populasi penelitian berjumlah 43 orang. Analisis data menggunakan uji $\mathrm{X}^{2}$ (Chi Square). Hasil penelitian menunjukan yang pernah mengalami kecelakaaan kerja sebanyak 40 orang. Jenis kecelakaan kerja tersebut adalah terpeleset $(11,6 \%)$, tertusuk $(48,8 \%)$, Tersayat $(32,6 \%)$. Bagian tubuh yang terluka yang banyak menimpa adalah pada tangan $(69,8 \%)$. Hasil penelitian menunjukan ada hubungan usia dan tingkat pendidikan $(\mathrm{p}<0,05)$ dengan terjadinya kecelakaan kerja. Upaya pengendalian dilakukan dengan membuat ruang kerja yang nyaman, jadwal istirahat yang cukup, pengadaan alat pelindung diri (APD) yang sesuai dengan potensi bahaya yang ada.
\end{abstract}

Kata Kunci $\quad$ : Faktor manusia, kecelakaan kerja,industri meubel Aluminium

\section{PENDAHULUAN}

Keselamatan kerja bertujuan menjamin keadaan, keutuhan dan kesempurnaan, baik jasmani maupun rohaniah manusia, serta hasil karya dan budayanya tertuju pada kesejahteraan masyarakat pada umumnya dan pekerja pada khususnya. Jadi dapat disimpulkan, bahwa keselamatan kerja pada hakekatnya adalah usaha manusia untuk melindungi hidupnya dan yang berhuhubungan dengan itu, dengan melakukan tindakan preventif dan pengamanan terhadap terjadinya 
kecelakaan kerja ketika kita sedang bekerja (5).

Kabupaten di Hulu Sungai Utara selain sudah dikenal sebagai lumbung peternakan Itik dan Kerbau, namun dikenal juga sebagai sentra pengolahan meubel kayu dan alumunium atau industri yang bergerak pada sektor informal sebagai komoditas unggulan. Sebagai daerah yang tidak banyak memiliki potensi sumber daya alam, Kabupaten Hulu Sungai Utara dipacu untuk terus berkreasi dengan memajukan komuditas unggulannya tersebut, yakni dijadikan juga sebagai potensi pendapatan daerah.

Berdasarkan data hasil survey pendahuluan melalui wawancara dari beberapa pemilik industri yang memiliki industri meubel aluminium ini yang berjumlah 16 buah industri di desa Banyu Tajun, Kecamatan Sungai Pandan yang masing-masing rumah memiliki 3 pekerja dengan jam kerja selama 10 jam bahkan lebih serta semua pekerja tidak pernah memakai alat pelindung diri saat melakukan pekerjaanya. Dalam pengolahan meubel kayu cuma terkendala bahan baku yang harganya mahal, kayu yang sering digunakan adalah kayu lurus, kayu Jati hanya untuk pesanan saja. Mahalnya bahan baku itulah, membuat para pengrajin pindah ke pengolahan meubel alumunium, disamping bahan bakunya mudah didapat, harganya juga murah dan mata pencaharian masyarakat tersebut adalah pengrajin meubel aluminium mereka melakukan pekerjaan ini bisa dibilang secara turun-temurun dan tidak ada perusahan yang resmi yang menaungi pengrajin tersebut. Pengarajin meubel di Banyu Tajun melakukan kegiatan atau usahanya di masing-masing rumah mereka serta dari pembelian bahan baku melalui pengeluaran mereka sendiri.

Kejadian kecelakaan kerja pada industri sektor informal dengan proses produksi hampir sama dengan sentra di industri meubel di Desa Banyu Tajun. Pada saat produksi meubel aluminium sering terjadi kecelakaan kerja seperti tersayat, terpotong, kejatuhan barang, terpeleset, dan terjatuh. Kecelakaan akibat kerja tersebut disebabkan oleh kurangnya hati-hati dalam bekerja serta tidak mempedulikan kondisi lingkungan sekitar. Kejadian kecelakaan kerja tersebut dihubungkan dengan faktor unsafe action yaitu tindakan tenaga kerja yang tidak benar.

Secara umum penelitian ini bertujuan untuk mengetahui hubungan faktor manusia dengan terjadinya kecelakaan kerja pada sentra industri meubel aluminium. Mengidentifikasi karakteristik pekerja (usia, tingkat pendidikan, masa kerja, status perkawinan). Mengetahui tahapan proses produksi. Mengetahui hazard potensial kegiatan proses produksi. Mengetahui klasifikasi kecelakaan akibat kerja berdasarkan jenis luka, sifat luka, dan letak luka di sentra Industri meubel aluminium. Mengetahui hubungan usia, tingkat pendidikan, masa kerja, dan status perkawinan dengan terjadinya kecelakaan kerja di sentra industri meubel aluminium di Desa Banyu Tajun, Kecamatan Sungai Pandan, Kabupaten Hulu Sungai Utara tahun 2016.

\section{BAHAN DAN CARA PENELITIAN}

Desain dalam penelitian ini adalah dengan Cross Sectional, yaitu data yang menyangkut variabel bebas (usia, tingkat pendidikan, masa kerja, status perkawinan) dan variabel terikat (kecelakaan kerja) akan dikumpulkan dalam waktu yang bersamaan dan secara langsung. Populasi penelitian ini adalah seluruh pekerja pada unit usaha di sentra industri pembuatan meubel aluminium yang ada di Desa Banyu Tajun, Kecamatan Sungai Pandan, Kabupaten Hulu Sungai Utara berjumlah 48 orang pekerja.. Yang men jadi variabel penelitian ini adalah variabel bebas yaitu usia, tingkat pendidikan, masa kerja, dan status perkawinan. Variabel terikat yaitu kecelakaan kerja. Metode pengumpulan data yaitu menggunakan Purposive Sampling adalah teknik penentuan sampel dengan pertimbangan tertentu (15). Cara pengumpulan data yaitu melalui observasi dan kuesioner dengan pekerja meubel Aluminium. Pengolahan data yaitu menggunakan analisis uji $\mathrm{X}^{2}$ (ChiSquare). 


\section{HASIL DAN PEMBAHASAN}

Hasil distribusi karakteristik pekerja berdasarkan usia responden pada Industri Meubel Aluminium Tahun 2016 dapat dilihat pada Tabel 1.

Tabel 1. Usia Responden

\begin{tabular}{|c|c|c|}
\hline Usia & $\begin{array}{l}\text { Jumlah } \\
\text { (orang) }\end{array}$ & (\%) \\
\hline $\begin{array}{l}\text { Muda } \\
\text { (<30 Tahun) }\end{array}$ & 31 & 72,1 \\
\hline $\begin{array}{l}\text { Tua } \\
(\geq 30 \text { Tahun })\end{array}$ & 12 & 27,9 \\
\hline Total & 43 & 100,0 \\
\hline
\end{tabular}

Berdasarkan Tabel 1 diketahui bahwa dari 43 responden yang terbanyak adalah responden dengan kelompok usia muda $<30$ tahun yaitu sebanyak 31 orang $(72,1 \%)$, dan kelompok usia $\geq 30$ tahun sebanyak 12 orang $(27,9 \%)$.

Hasil distribusi karakteristik pekerja berdasarkan Tingkat Pendidikan responden pada Industri Meubel Aluminium Tahun 2016 dapat dilihat pada Tabel 2.

Tabel 2. Tingkat Pengetahuan Responden

\begin{tabular}{lcc}
\hline \multicolumn{1}{c}{$\begin{array}{c}\text { Tingkat } \\
\text { Pendidikan }\end{array}$} & $\begin{array}{c}\text { Jumlah } \\
\text { (orang) }\end{array}$ & (\%) \\
\hline $\begin{array}{l}\text { Pendidikan Dasar } \\
\text { (SD-SMP) }\end{array}$ & 32 & 74,4 \\
$\begin{array}{l}\text { Pendidikan Menengah } \\
\text { (SLTA sederajat) }\end{array}$ & 11 & 25,6 \\
\hline \multicolumn{1}{c}{ Total } & & \\
\hline
\end{tabular}

Berdasarkan Tabel 2 diketahui bahwa dari 43 responden yang terbanyak adalah responden dengan kelompok pendidikan dasar (SD-SMP) yaitu sebanyak 32 orang $(74,4 \%)$, dan kelompok pendidikan menengah (SLTA sederajat) sebanyak 11 orang $(25,6 \%)$.

Hasil distribusi karakteristik pekerja berdasarkan Masa Kerja responden pada Industri Meubel Aluminium Tahun 2016 dapat dilihat pad Tabel 3.

Tabel 3. Masa Kerja Responden

$$
\text { Masa Kerja Jumlah (\%) }
$$

(orang)

\begin{tabular}{ccr}
\hline Baru $<3$ Tahun & 26 & 60,5 \\
Lama $\geq 3$ Tahun & 17 & 39,5 \\
\hline Total & 43 & 100,0 \\
\hline
\end{tabular}

Berdasarkan Tabel 3 diketahui bahwa dari 43 responden yang terbanyak adalah responden dengan kelompok masa kerja baru $<3$ tahun yaitu sebanyak 26 orang $(60,5 \%)$, dan kelompok masa kerja lama $\geq 3$ tahun sebanyak 17 orang $(39,5 \%)$.

Tahapan proses produksi meubel Aluminium secara rinci adalah penyiapan bahan baku, penyiapan bahan baku, pemotongan, pembentukan, perakitan, dan proses finishing yang dipasarkan diberbagai daerah diseluruh Kalimantan Selatan.

Tabel 4 menjelaskan klasifikasi kecelakaan akibat kerja yang terjadi pada proses produksi meubel aluminium.

Tabel 4. Klasifikasi Kecelakaan Akibat Kerja (KAK)

\begin{tabular}{|c|c|c|c|c|c|c|c|}
\hline \multirow[t]{2}{*}{ No } & \multirow{2}{*}{$\begin{array}{l}\text { Tahapan } \\
\text { proses } \\
\text { produksi }\end{array}$} & \multicolumn{4}{|c|}{ Klasifikasi KAK } & \multirow{2}{*}{$\begin{array}{l}\text { Hilang } \\
\text { Hari } \\
\text { Kerja }\end{array}$} & \multirow[t]{2}{*}{ Waktu KAK } \\
\hline & & jenis & Penyebab & $\begin{array}{l}\text { Sifat } \\
\text { luka }\end{array}$ & $\begin{array}{l}\text { Letak } \\
\text { luka }\end{array}$ & & \\
\hline 1 & $\begin{array}{l}\text { Penyiapa } \\
\text { n bahan } \\
\text { baku }\end{array}$ & $\begin{array}{l}\text { Tersa } \\
\text { yat }\end{array}$ & $\begin{array}{l}\text { Tersayat } \\
\text { saat } \\
\text { mengangk } \\
\text { at kaca }\end{array}$ & $\begin{array}{l}\text { Luka } \\
\text { permuk } \\
\text { aan }\end{array}$ & tangan & 1 hari & $\begin{array}{l}\text { Saat membuka } \\
\text { lapisan lapisan } \\
\text { kaca }\end{array}$ \\
\hline 2 & $\begin{array}{l}\text { Pemoton } \\
\text { gan }\end{array}$ & $\begin{array}{l}\text { Tersa } \\
\text { yat }\end{array}$ & $\begin{array}{l}\text { Tersayat } \\
\text { saat } \\
\text { memotong } \\
\text { kaca }\end{array}$ & $\begin{array}{l}\text { Luka } \\
\text { permuk } \\
\text { aan }\end{array}$ & tangan & 1 hari & $\begin{array}{l}\text { Saat } \\
\text { memotong- } \\
\text { motong kaca }\end{array}$ \\
\hline
\end{tabular}




\begin{tabular}{|c|c|c|c|c|c|c|c|}
\hline \multirow[t]{2}{*}{ No } & \multirow{2}{*}{$\begin{array}{l}\text { Tahapan } \\
\text { proses } \\
\text { produksi }\end{array}$} & \multicolumn{4}{|c|}{ Klasifikasi KAK } & \multirow{2}{*}{$\begin{array}{l}\text { Hilang } \\
\text { Hari } \\
\text { Kerja }\end{array}$} & \multirow[t]{2}{*}{ Waktu KAK } \\
\hline & & jenis & Penyebab & $\begin{array}{l}\text { Sifat } \\
\text { luka }\end{array}$ & $\begin{array}{l}\text { Letak } \\
\text { luka }\end{array}$ & & \\
\hline 3 & $\begin{array}{l}\text { Pembent } \\
\text { ukan }\end{array}$ & $\begin{array}{l}\text { Tertu } \\
\text { suk }\end{array}$ & $\begin{array}{l}\text { Peralatan } \\
\text { kerja }\end{array}$ & $\begin{array}{l}\text { Luka } \\
\text { permuk } \\
\text { aan,me } \\
\text { mar }\end{array}$ & tangan & - & $\begin{array}{l}\text { Saat } \\
\text { pebentukan } \\
\text { aluminium dan } \\
\text { kaca }\end{array}$ \\
\hline 4 & Perakitan & $\begin{array}{l}\text { Tertu } \\
\text { suk, } \\
\text { Tersa } \\
\text { yat }\end{array}$ & $\begin{array}{l}\text { Peralatan } \\
\text { kerja }\end{array}$ & $\begin{array}{l}\text { Luka } \\
\text { permuk } \\
\text { aan dan } \\
\text { memar }\end{array}$ & tangan & - & $\begin{array}{l}\text { Saat merakit } \\
\text { lemari,rk } \\
\text { sepatu dsb }\end{array}$ \\
\hline 5 & Finishing & $\begin{array}{l}\text { Terpe } \\
\text { leset, } \\
\text { Tersa } \\
\text { yat }\end{array}$ & $\begin{array}{l}\text { Lingkunga } \\
\text { n kerja } \\
\text { (tindakan } \\
\text { pekerja } \\
\text { yang tidak } \\
\text { aman) }\end{array}$ & $\begin{array}{l}\text { Memar, } \\
\text { luka } \\
\text { permuk } \\
\text { aan, } \\
\text { keseleo }\end{array}$ & Kaki & 1 hari & $\begin{array}{l}\text { Saat } \\
\text { pengepakan } \\
\text { barang }\end{array}$ \\
\hline
\end{tabular}

Tabel 5. Hubungan Usia Dengan Terjadinya Kecelakaan Kerja Pada Industri Meubel Aluminium Tahun 2016.

\begin{tabular}{ccccccc}
\hline $\begin{array}{c}\text { Usia } \\
\text { (Tahun) }\end{array}$ & \multicolumn{4}{c}{ Kecelakaan Kerja } & \multirow{2}{\text{Jumlah}}{ (orang) } & P- Value \\
\cline { 2 - 5 } & Pernah & \% & Tidak Pernah & \% & & \\
\hline Muda $<30$ & 31 & $\begin{array}{c}10 \\
0\end{array}$ & 0 & 0 & 31 & 0,018 \\
Tua $\geq 30$ & 9 & 75 & 3 & 25 & 12 & \\
\hline Jumlah & 40 & & 3 & & 43 & \\
\hline
\end{tabular}

Tabel 5 di atas dan berdasarkan hasil uji statistik, ada hubungan kejadian kecelakaan kerja pada usia muda $\leq$ 30tahun dan usia tua $\geq 30$ tahun atau dengan kata lain ada hubungan antara usia responden dengan terjadinya kecelakaan kerja.

Hubungan tingkat pendidikan dengan terjadinya kecelakaan kerja dapat dilihat pada Tabel 6.

Tabel 6. Hubungan Tingkat Pendidikan Dengan Terjadinya Kecelakaan Kerja Pada Industri Meubel Aluminium Tahun 2016.

\begin{tabular}{|c|c|c|c|c|c|c|}
\hline \multirow[t]{2}{*}{ Tingkat Pendidikan } & \multicolumn{4}{|c|}{ Kecelakaan Kerja } & \multirow{2}{*}{$\begin{array}{l}\text { Jumlah } \\
\text { (orang) }\end{array}$} & \multirow[t]{2}{*}{ P-Value } \\
\hline & Pernah & $\%$ & $\begin{array}{r}\text { Tidak } \\
\text { Pernah }\end{array}$ & $\%$ & & \\
\hline $\begin{array}{l}\text { Pendidikan Dasar (SD- } \\
\text { SMP) }\end{array}$ & 32 & 100 & 0 & 0 & 32 & \\
\hline $\begin{array}{l}\text { Pendidikan Menengah } \\
\text { (SLTA sederajat) }\end{array}$ & 8 & 72,7 & 3 & 27,3 & 11 & 0,013 \\
\hline Total & 40 & & 3 & & 43 & \\
\hline
\end{tabular}

Hasil uji statistik berarti ada hubungan kejadian kecelakaan kerja pada tingkat pendidikan dasar (SD-SMP) dan tingkat pendidikan menengah, atau dengan kata lain ada hubungan antara tingkat pendidikan responden dengan terjadinya kecelakaan kerja. 
Tabel 7. Hubungan Masa Kerja Dengan Terjadinya Kecelakaan Kerja Pada Industri Meubel Aluminium Tahun 2016.

\begin{tabular}{ccccccc}
\hline \multirow{2}{*}{$\begin{array}{c}\text { Masa Kerja } \\
\text { (Tahun) }\end{array}$} & Pernah & $\%$ & Tidak Pernah & $\mathbf{\%}$ & Jumlah & P- Value \\
(orang) & & \\
\hline Baru $<3$ & 26 & 100 & 0 & 0 & 26 & 0,055 \\
Lama $\geq 3$ & 14 & 82,4 & 3 & 17,6 & 17 & \\
\hline Total & 40 & & 3 & & 43 & \\
\hline
\end{tabular}

Hasil uji statistik, berarti tidak ada hubungan kejadian kecelakaan kerja pada masa kerja $\leq 3$ tahun dan masa kerja $\geq 3$ tahun atau dengan kata lain tidak ada hubungan antara masa kerja responden dengan terjadinya kecelakaan kerja.

\section{PEMBAHASAN}

Usia pekerja dapat menjadi penyebab terjadinya kecelakaan kerja. Pada pekerjaan yang banyak memerlukan tenaga, biasanya dipilih pekerja yang masih muda karena fisiknya masih kuat, tetapi usia muda ini biasanya masih penuh dengan sikap emosi, ceroboh, serta kurangnya pengalaman.

Seorang pekerja yang tingkat pendidikannya rendah akan sering terlambat atau ragu-ragu dalam pengambilan keputusan, maka kondisi ini akan mengundang terjadinya kecelakaan kerja.

Masa kerja pekerja pada industri Meubel Aluminium sebagian besar memiliki masa kerja yang baru karena banyak yang pindah pekerjaan yang dulunya bekerja di meubel kayu berpindah menjadi pekerja meubel Aluminium.

Proses produksi ini bahan baku yang digunakan yaitu Aluminium dan kaca. Berdasarkan hasil penelitian setiap tahapan proses produksi berpotensi mengalami kecelakaan kerja dilihat dari tenaga kerja, aktivitas produksi, dan lingkungan kerja. Pada tahapan proses produksi bangunan tempat memproduksi meubel Aluminium, ruangan pada semua tahapan dilakukan dalam satu ruangan atau tanpa ada pembagian setiap tahapan produksi dan kurangnya penerangan di tempat tersebut, jadi potensi bahaya kecelakaan akibat kerja yang ditimbulkan seperti tersayat dan tertusuk sering ditemukan di.tempat kerja.

Berdasarkan hasil observasi di Industri meubel Aluminium pada hazard potential KAK, Kecelakaan pada masing masing proses dapat berbeda - beda, namun secara keseluruhan kecelakaan akibat kerja yang dapat terjadi pada proses produksi adalah tertusuk, tersayat, dan terpeleset saat finishing. Secara keseluruhan KAK terjadi pada saat responden bekerja. letak luka yang dialami pekerja bila terjadi KAK tersebut adalah pada anggota badan (tangan,Jari dan kaki) dan hilang hari kerja selama 1 hari.

Berdasarkan hasil uji statistik, menggunakan Uji chi-square dan hasil ini didasarkan pada uji alternatif Fisher Exact Test diperoleh nilai p-Value $=0,018$. Dengan demikian p-Value hitung < pValue alpha $(0,05)$, sehingga Ho Ditolak, berarati ada hubungan kejadian kecelakaan kerja pada usia muda $\leq$ 30 tahun dan usia tua $\geq 30$ tahun, atau dengan kata lain dapat disimpulkan bahwa ada hubungan antara usia responden dengan terjadinya kecelakaan kerja pada Industri Meubel Aluminium Di Desa Banyu Tajun, Kecamatan Sungai Pandan, Kabupaten Hulu Sungai Utara Tahun 2016.

Faktor usia sebagai penyebab terjadinya kecelakaan kerja, terutama pada usia muda biasanya masih penuh dengan emosi, ceroboh, serta kurangnya pengalamam, sehingga sering menimbulkan tindakan yang membahayakan keselamatannya. Salah 
satu faktor penting lainnya sebagai sebab kecelakaan pada tenaga kerja muda adalah kurangnya perasaan tanggung jawab (Salamo Perangin-angin, 2007).

Berdasarkan hasil uji statistik, menggunakan uji chi-square dan hasil ini didasarkan pada uji alternatif Fisher Exact Test diperoleh nilai p-value $=0,013$. Dengan demikian $\mathrm{p}$-Value hitung $<\mathrm{p}$ Value alpha $(0,05)$, sehingga Ho Ditolak, berarati ada hubungan kejadian kecelakaan kerja pada pendidikan dasar (SD-SMP) dan pendidikan menengah(SLTA sederajat), atau dengan kata lain dapat disimpulkan bahwa ada hubungan antara tingkat pendidikan responden dengan terjadinya kecelakaan kerja pada Industri Meubel Aluminium Di Desa Banyu Tajun, Kecamatan Sungai Pandan, Kabupaten Hulu Sungai Utara Tahun 2016.

Tingkat pendidikan sangat mempengaruhi kecakapan seseorang dalam melakukan pekerjaan.Tingkat pendidikan juga berhubungan dengan cepat atau lambatanya tenaga kerja dalam mengambil keputusan.

Berdasarkan hasil uji statistik, menggunakan uji chi-square dan hasil ini didasarkan pada uji alternatif Fisher Exact Test diperoleh nilai p-Value $=0,055$. Dengan demikian $\mathrm{p}$-Value hitung $>\mathrm{p}$-Value alpha $(0,05)$, sehingga Ho Diterima, berarati tidak ada hubungan kejadian kecelakaan kerja pada masa kerja baru $\leq$ 3 tahun dan masa kerja lama $\geq 3$ tahun, atau dengan kata lain dapat disimpulkan bahwa tidak ada hubungan antara masa kerja responden dengan terjadinya kecelakaan kerja pada Industri Meubel Aluminium Di Desa Banyu Tajun, Kecamatan Sungai Pandan, Kabupaten Hulu Sungai Utara Tahun 2016.

Hal ini sesuai dengan pernyataan Suma'mur (2011) yang mengemukakan bahwa pengalaman untuk waspada terhadap kecelakaan kerja bertambah baik sesuai dengan pertambahan masa kerja dan lama bekerja di tempat kerja yang bersangkutan. Berdasarkan hasil uji statistik, menggunakan uji chi-square dan hasil ini didasarkan pada uji alternatif Fisher Exact Test diperoleh nilai p-value= 0,064. Dengan demikian p-Value hitung >
p-Value alpha $(0,05)$, sehingga Ho Diterima, berarati tidak ada hubungan kejadian kecelakaan kerja antara responden yang sudah kawin dan belum kawin,, atau dengan kata lain dapat disimpulkan bahwa tidak ada hubungan antara status perkawinan responden dengan terjadinya kecelakaan kerja pada Industri Meubel Aluminium di Desa Banyu Tajun, Kecamatan Sungai Pandan, Kabupaten Hulu Sungai Utara Tahun 2016.

Penyebab hal ini menunjukkan bahwa perilaku sebelum kawin dan sesudah kawin tidak terjadi perbedaan di industri meubel Aluminium, biasanya orang yang sudah kawin lebih berhati-hati karena keluarga menunggu dirumah namun ada juga yang berpendapat pekerja yang dalam menjalankan tugas dimana pikirannya dibebani berbagai macam masalah,yaitu masalah rumah tangga.

\section{KESIMPULAN DAN SARAN}

Karakteristik responden meliputi usia muda sebanyak 72,1\%, tingkat pendidikan yaitu pendidikan dasar sebanyak 74,4\%, masa kerja baru $\leq 3$ tahun sebanyak 65,1 \%, dan status perkawinan diketahui sebanyak 83,7\% yang sudah kawin. Tahapan proses produksi yang ada di industri meubel Aluminium terdiri dari penyiapan bahan baku, pemotongan, pembentukan, perakitan, dan proses finishing yang dipasarkan diberbagai daerah diseluruh Kalimantan Selatan.Hazard potential pada kegiatan proses produksi meubel Aluminium, secara keseluruhan bahaya fisik yang dapat terjadi adalah suhu/tekanan panas, bahaya kimia adalah debu, bahaya biologi adalah vektor/nyamuk, bahaya fisiologi adalah low back pain/keram pada anggota tubuh dan bahaya psikologi yang umum terjadi adalah stress. Klasifikasi kecelakaan akibat kerja secara keseluruhan yang dapat terjadi pada proses produksi adalah tertusuk, tersayat dan terpeleset dengan media penyebab kecelakaan diperalatan kerja maupun dilingkungan kerja dan hilang hari kerja sebanyak 1 hari. Ada hubungan antara usia responden dengan 
terjadinya kecelakaan kerja. Ada hubungan antara tingkat pendidikan responden dengan terjadinya kecelakaan kerja. Tidak ada hubungan antara masa kerja responden dengan terjadinya kecelakaan kerja. Tidak ada hubungan antara status perkawinan responden dengan terjadinya kecelakaan kerja.

Dapat disarankan bagi pemilik usaha Menyediakan APD yang cukup sesuai dengan potensi bahaya yang ada. Menciptakan lingkungan kerja yang aman dan nyaman. Membuat izin usaha kepada dinas terkait. Peningkatan pengawasan kegiatan proses produksi dimeubel Aluminium sehingga pekerja mempunyai perilaku bekerja yang lebih aman seperti memakai APD saat bekerja Bagi Pekerja Untuk lebih meningkatkan kesadaran akan pentingnya keselamatan kerja agar dapat mencapai produktifitas kerja yang maksimal dan terhindar dari kecelakaan akibat kerja.

\section{KEPUSTAKAAN}

1. Andriana, M (2008). Analisis Kecelakaan Kerja Pada Pekerja Industri Pembuatan Pintu, Kusen Dan Jendela. Banjarbaru

2. Badan Pusat Statistik Kabupaten Hulu Sungai Utara. 2015. http://hulusungaiutarakab.go.id/asse ts/docs/Statistik-Daerah-KabupatenHulu-Sungai- Utara-2015.pdf. Diakses tanggal 1 Febuari 2016.

3. Budiono Sugeng, 2003, Bunga Rampai Hiperkes dan $K K$, Semarang: Badan Penerbit Universitas Diponegoro Semarang.

4. Colling D.A (1990).Fire prevention and protection. Safety Mangement and tehnology

5. Daryanto.2002. Keselamatan Dan Kesehatan Kerja. Malang: Rineka Cipta.

6. Dinas Perindustrian, Perdagangan, Penanaman Modal, Penanaman Modal dan Koperasi Provinsi Kalimantan Selatan.2008.Pertumbuhan Ekonomi Sektor Informal Provinsi Kalimantan Selatan Tahun 2008.

7. Erliyanti, E. D. (2009). Hubungan Faktor Manusia Dengan Terjadinya
Kecelakaan Kerja Pada Industri Kayu

Lapis PT. Basirih Industrial Corporation.Banjarbaruhttp://www.d epkes.go.id,2003.

8. http://www.depkes.go.id,2008.

9. http://www.depkes.go.id,2009.

10. http://www.depkes.go.id,2014.

11. Infodatin. 2014.Direktorat Bina Kesehatan Kerja dan Olahraga Kementerian Kesehatan

12. Kurniawati, E., Sugiono, \& Yuniarti, R. (2012). Analisis Potensi Kecelakaan Kerja Pada Departemen Produksi Springbed Dengan Metode Hazard Identification and risk Assesment. Jurusan Teknik Industri Universitas Brawijaya .

13. Soekidjo Notoatmodjo, 2003, Ilmu Kesehatan Masyarakat PrinsipPrinsip Dasar, Jakarta: Rineka Cipta.

14. Sucipto, Cecep Dani. 2014.Keselamatan dan Kesehatan Kerja. Yogyakarta :Gosyen Publishing.

15. Sugiyono, P. D. 2006. Statistika Untuk Penelitian. Bandung: Alfabeta.

16. Suma'mur, 1996. Keselamatan Kerja dan Pencegahan Kecelakaan. Jakarta: CV Haji Masagung.

17. Triwibowo Cecep, M. E. 2013.Kesehatan Lingkungan dan K3. Yogyakarta: Nuha Medika

18. UU NO. 1 Tahun 1970 Tentang Keselamatan Kerja.

19. UU NO. 13 Tahun 2003 Tentang Ketenagakerjaan. 